\title{
Vietnamese Boat People: The Stories of Vietnamese Refugees and their Journey in Seeking Asylum in Canada during the Late 1970 s to the $1980 \mathrm{~s}$
}

\section{Connie Tran}

\section{Introduction}

In the years following the Vietnam War (1975) and especially during the years leading up to the Sino-Vietnamese War in 1978, more than one million refugees were forced to flee the war-torn countries of Vietnam, Cambodia and Laos. The Vietnamese people who were displaced from their homes were placed in refugee camps all over south eastern Asia in countries such as Malaysia, Indonesia, Thailand, Philippines, and Singapore along with the southern parts of China and the British colony of Hong Kong. To many western countries like Canada and the United States these Vietnamese refugees were known as the "boat people" due to their mode of transportation: small overcrowded boats. Those who survived the treacherous journey had no choice but to stay in the refugee camps for months, while others stayed for years. Those who were fortunate were taken in by developed countries around the world such as the United States, Canada, France, and Australia through sponsorship programs arranged by the government or through private sponsorship programs created by Christian churches and organizations, corporations, and even family members or sympathetic individuals who just wanted to help.

This essay will examine the lives of these boat people during their times as a displaced person and their journey to Canada. It will also examine the policies and programs that made it possible for them to be resettled in Canada, along with the public opinion surrounding these Vietnamese refugees. More specifically, this essay will answer several questions: what were the causes of the Vietnam War and the Sino-Vietnamese war that led to over one million Southeast Asians, specifically Vietnamese refugees, to flee their country? What was life like as a refugee and what were the conditions like on the boats and in the refugee camp? Finally, how did the Western world, especially the Canadian government, play a role in aiding these refugees?

These questions will be answered through a variety of secondary and primary sources such as monographs, journal articles, news articles, government documents, interviews, and other sources. One source in particular centers on the story of a Vietnamese refugee family and their journey in becoming Canadian citizens.

As an ethnic Chinese Vietnamese-born Canadian citizen, Mr. Nguyen, his younger sister and their younger brother were once refugees during the late 1970s and the early 1980s. ${ }^{1}$ Born to ethnic Chinese parents in 1955 in Northern Vietnam, Mr. Nguyen and his siblings, like many other ethnic Chinese Vietnamese citizens, were persecuted by the communist regime in 1978. Fortunately for the family, Mr. Nguyen's younger sister arrived in Canada a year before her brothers and was able to sponsor them through the same

\footnotetext{
1 The identity of the Nguyen family have been altered for privacy reasons.
} 
private Christian sponsorship program that brought her to Winnipeg, Manitoba nearly 35 years ago.

\section{The Vietnam War (1951-1975) and the Sino-Vietnamese War (1979)}

The Vietnam War and the Sino-Vietnamese War were the results of the rising fear of the spread of communism in Asia. When the Americans became involved, the war shifted from a colonial war - where France tried to control and prevent its colony from acquiring independence with the help of American troops - to a war where the United States tried to combat the communist regime that was spreading throughout the country, especially in North Vietnam. 2 August 1964 marked a critical point in America's involvement in Vietnam. In what is known as the Gulf of Tonkin incident, a group of North Vietnamese torpedo boats fired several torpedoes at the USS Maddox after being attacked by the destroyer. ${ }^{2}$ As a result, the Johnson Administration passed the Gulf of Tonkin Resolution on 7 August 1964 to allow President Lyndon B. Johnson to use military force against North Vietnam. ${ }^{3}$ From there the President would authorize more bombings to try to defeat the communists.

One campaign in particular was Operation Rolling Thunder. It was a gradual aerial bombing campaign against North Vietnam that started on 2 March 1965 to 2 November 1968. The objectives were to weaken North Vietnam by bombing major transportation systems and military bases to prevent the communists from entering South Vietnam, boost the morale in South Vietnam, and weaken the North enough so that they would consider negotiations. ${ }^{4}$ Many historians have considered this campaign to be a failure due to its ineffectiveness which eventually cost America the war. In fact, Operation Rolling Thunder was supposed to only last for 28 days, but shortly after, the Joint Chiefs of Staff (JCS) extended it to three months. ${ }^{5}$ The campaign actually lasted for more than two-and-a-half years due to the unexpected resistance from the North who received support from the Soviet Union and the People's Republic of China.

Despite the failure of the campaign, it did cause major damage. According to an appraisal report (1 April - 30 June 1968) prepared by the Central Intelligence Agency and the Defense Intelligence Agency, an estimated value of damage inflicted on North Vietnam from the campaign's start in March 1965 to June 1968 was $\$ 459$ million. $^{6}$ While the amount is not official, numerous sources have estimated that more than 50,000 deaths during Operation Rolling Thunder were civilian deaths. According to the 1966 declassified CIA memorandum on Operation Rolling Thunder, during the period between early May and June 1966, "airstrikes against North Vietnam were concentrated in the area south of Hanoi,

\footnotetext{
${ }^{2}$ Bradley Philip Mark, Vietnam at War, (Oxford: Oxford University Press, 2009), 109.

${ }^{3}$ Ibid, 109.

${ }^{4}$ Ibid, 110-111.

${ }^{5}$ Stephen W. Wilson, "Taking Clodfelter One Step Further: Mass, Surprise, Concentration, and the Failure of Operation Rolling Thunder," Air Power History, 48, no. 4 (2001): 40-47, http://library.mtroyal.ca:2081/ docview/219749982?pq-origsite=summon (accessed November 8, 2014).

${ }^{6}$ Central Intelligence Agency, and the Defense Intelligence Agency, "An Appraisal of the Bombing of North Vietnam (1 April - 30 June 1968)," Central Intelligence Agency Collection, Folder 148, Box 11, (MORI Document ID: 14451:14451), (The Vietnam Center and Archive: Texas Tech University, July 1968): 3, http:// www.vietnam.ttu.edu/virtualarchive/items.php?item=04111148001 (accessed November 29, 2014).
} 
with some strikes in the northeast area." ${ }^{7}$ As Mr. Nguyen recalled, on 12 June 1966, a Sunday afternoon, American fighter jets flew over his small town, which was located west of the North Vietnamese city of Móng Cái in Quảng Ninh Province. The aircraft dropped three bombs. One of the bombs did not detonate while the other two did. As a result, many were injured and four people were killed that day, including Mr. Nguyen's father. ${ }^{8}$ At 11 years old Mr. Nguyen, his older sister and four younger siblings were raised by their paternal grandparents.

The turning point of the war occurred on January 1968 when the North Vietnamese troops and the Viet Cong guerrillas launched a major attack against 36 provincial capitals in the South, including Saigon, and many military bases. ${ }^{9}$ As a result, morale in South Vietnam and in the United States were low, and American support for the war was rapidly declining. Prior to the fall of Saigon major chaos erupted as the communist regime began to take control. During this period many Vietnamese people and American citizens in Vietnam decided they could no longer stay, so they fled the country by boat, land or by aircraft. Those who successfully evacuated were fortunate enough to eventually reach the United States and resettle there. Those who were not as fortunate ended up staying in Vietnam. Some were placed in re-education camps where they were forced to do hard labour. In a CBC interview, Vietnamese refugee Francis Win recalled that his father, who was a deputy Premiere in the South Vietnamese government, was placed in a re-education camp to do hard labour for nearly three years. When he was finally released, he and his family decided to flee the country and ended up in Canada, where approximately 2,000 Vietnamese people were taken in by the Canadian government in the month of April that year. ${ }^{10}$

On 2 July 1976, South Vietnam and North Vietnam united to for the Socialist Republic of Vietnam. Two years later, Vietnam invaded Democratic Kampuchea (Cambodia) after border disputes. In response, China declared war against Vietnam starting the SinoVietnamese War, which only lasted for 28 days from 17 February to 16 March 1979, but had massive ramifications. Before and especially during this time, the ethnic Chinese population in Vietnam (known as the Hoa people) faced heavy repression and discrimination from the Vietnamese government. Indeed, Vietnamese citizens who had Chinese blood or were related to a Chinese person were often told to leave the country. In fact, one 31 year old man named Nguyen Van Minh was taken in by the police and questioned for having a Chinese grandmother, despite being a Soviet-trained civil engineer from Hanoi and a party member. Due to his lineage he was asked to either leave Vietnam by

\footnotetext{
${ }^{7}$ Director of Intelligence, "Intelligence Memorandum: An Appraisal of the Bombing of North Vietnam (Through 14 June)," Central Intelligence Agency Collection, Folder 27, Box 02, (MORI Document ID: 9128:9128), (The Vietnam Center and Archive: Texas Tech University, June 20, 1966), http:// www.vietnam.ttu.edu/virtualarchive/items.php?item=0410227010 (accessed November 29, 2014): 2 .

${ }^{8}$ Mr. Nguyen, Mr. Nguyen's sister, interview by Connie Tran, Calgary, AB., Smart Phone Record, October 28, 2014.

${ }^{9}$ Sucheng Chan, The Vietnamese American 1.5 Generation: Stories of War, Revolution, Flight, and New Beginnings, (Philadelphia, PA: Temple University Press, 2006): 52.

${ }^{10}$ Puri, Belle, "Why they fled: The fall of Saigon," CBC Digital Archives, Guest interviewee Francis Win, Web, http://www.cbc.ca/archives/categories/society/immigration/boat-people-a-refugee-crisis/why-they-fledthe-fall-of-saigon.html.
} 
boat or be placed in a resettlement area. ${ }^{11}$ The Hoa people were most affected when the Vietnamese government decided to outlaw all private trade in March of 1978 and forced others to resettle in the New Economic Zones, which were overpopulated areas with very little government support. ${ }^{12}$ Consequently, many had no other choice but to leave their homeland.

\section{Fleeing Vietnam: Stories of the Refugees}

The major exodus of Vietnamese people occurred between 1978 and 1979. By the end of 1975, a large percentage of the boat people were ethnically Vietnamese who either left Vietnam illegally or at their own will. However, by 1979, about 80 percent of the Vietnamese refugees were ethnic Chinese as a result of the Vietnamese government forcing them form their homes. ${ }^{13}$ Many of them fled on foot or by boat. According to a 12 June 1979 New York Times article titled "Hanoi Regime Reported Resolve to Oust Nearly All Ethnic Chinese," Fox Butterfield reported that "exit fees" were imposed on the people fleeing the country, and in turn the Hanoi government made millions of dollars in revenue for it. ${ }^{14}$ Depending on who the would-be refugee was dealing with and which area of the country he or she was departing from, the cost of the "exit fee" was usually five to ten taels of gold (one tael was the equivalent of 37.79 grams of gold at that time, or about $\$ 3,000$ for ten taels of gold) for each adult leaving southern Vietnam. ${ }^{15}$ It was estimated that these fees made up the "largest single export commodity of Vietnam's threadbare economy" at that time, replacing coal as its leading export. ${ }^{16}$ Furthermore, those who wanted to escape by boat had to pay the owner and/or the captain a fee as well. According to Butterfield, most of the money was used to place a down payment of $\$ 100$ million to the Soviet Union for its aid and arms sales. The Vietnamese government and officials have denied this, but Butterfield reported that the exodus of the ethnic Chinese Vietnamese people was in fact organized by the Vietnamese government and that officials were looking for some help to expel them so that it would speed up the process. This was done by harassing the Hoa people, taking away their jobs, closing the schools, implementing a curfew and the use of intimidation and brute force by the police. ${ }^{17}$ Refugee trafficking also became a very lucrative business that some government officials became involved in.

However, while the "exit fees" did exist, it did not apply to everyone. In fact, when Mr. Nguyen and his family fled their home on 20 October 1978, they did not have to pay the fee. This was because the Nguyen family lived relatively close to the Vietnam-China border, and they fled the country earlier than most people who were seeking refuge, travelling by foot to China. ${ }^{18} \mathrm{He}$, his family - which consisted of his grandmother and grandfather, an

\footnotetext{
${ }^{11}$ Fox Butterfield, "Hanoi Regime Reported Resolve to Oust Nearly All Ethnic Chinese," The New York Times, June 12, 1979.

12 Mark, 176.

${ }^{13}$ Butterfield.

14 Ibid.

${ }^{15}$ Chan, 80.

${ }^{16}$ Butterfield.

${ }^{17}$ Ibid.

${ }^{18}$ Mr. Nguyen, Mr. Nguyen's sister, interview.
} 
older sister, two younger sisters (another younger sister was married and had left with her husband's family), and a younger brother - along with hundreds of his neighbours and other Hao North Vietnamese people walked north to the Chinese city of Dongxing. The entire journey took them twelve days. According to Mr. Nguyen, the only possessions that they could bring was whatever they could carry, and when it was night time they all had to sleep on the ground on the side of the road. ${ }^{19}$ When they finally arrived at the edge of the large motorway bridge that connected the two cities over the Beilun River, they were questioned and asked to provide their IDs. They did not have any papers or travel documents with them, but they were able to get into China because they all spoke Cantonese, which was a key indication that they were ethnic-Chinese Vietnamese citizens who were expelled from Vietnam.

After the screening they were immediately brought to a movie theater which was converted into a refugee camp site. ${ }^{20}$ They stayed at the site for more than two months, and in that time Mr. Nguyen claimed that while the living conditions were adequate life was still very difficult. The site they were staying in was overcrowded and they did not have enough to eat. They rarely got to leave the site and Mr. Nguyen claimed to have witnessed a lot of police brutality. In fact, according to a 1992 article published in the Pacific Basin Law Journal, the refugee camp site in Dongxing was particularly harsh because it was not known to international agencies as opposed to the sites in larger cities like Hong Kong and Macao. ${ }^{21}$ Similar to what Mr. Nguyen had claimed, the article also states that the refugees often complained about the little amount of food, the strict curfew hours, and that there was little to no medical care given at the camps. Furthermore, police brutality was a problem at the site because "men were often beaten or punished for small transgressions," and that the superintendent of the camp was known for committing cruel acts. For example, one superintendent was reported to have kicked a pregnant woman in the stomach, which resulted in a miscarriage. ${ }^{22}$

While the refugee camps did have its problems, the Chinese government did try to help the refugees. For example, many of the refugees were given a small ration of rice and a small stipend to help them meet certain needs. The Chinese government also gave out small plots of land or state farms where the refugees were expected to live, work, and grow their own food to feed their families. Two months after being interned in the refugee camps in Dongxing, the Chinese government gave Mr. Nguyen and his family one of the state farms. They were also given a monthly ration of rice, they received new clothes and a small house that came with the farm. ${ }^{23}$ It was then that they were allowed to find a job. Mr. Nguyen worked in a restaurant and earned approximately $\$ 28$ a month. While the Nguyens were fortunate to receive these aids, in most cases these were only temporary fixes and gaining permanent residency in China was very difficult. One of the main reasons why many of the

\footnotetext{
${ }^{19}$ Mr. Nguyen, Mr. Nguyen's sister, interview.

20 Ibid.

${ }^{21}$ Dinah PoKempner, "Indefinite Detention and Mandatory Repatriation: The Incarceration of Vietnamese in Hong Kong," Pacific Basin Law Journal, 10, no. 2 (1992): 19, http://escholarship.org/uc/item/5k50w30x? query=dongxing;hitNum=1

22 Ibid., 19.

${ }^{23}$ Mr. Nguyen, Mr. Nguyen's sister, interview.
} 
Southeast Asian countries like Malaysia, the Philippines, and China agreed to take in the Vietnamese refugees in the first place was because they understood that other countries, especially the developed nations in the west who were a part of the Geneva Accord - in particular the United States of America, Canada, and Australia - would offer the refugees permanent asylum. ${ }^{24}$

Several months after living in Dongxing, Mr. Nguyen's younger sister left the city to go to Hong Kong with her husband and his family hoping that they would have a better chance in seeking asylum in a western country. They travelled from Dongxing to Hong Kong by boat in a dangerous two month long trip out at sea. This had to be done secretly because if they were caught they would be immediately apprehended and deported back if they were suspected to have been a resident in one of the Chinese refugee camp. In fact, under an agreement between Hong Kong and the Chinese government, these people known as Chinese illegal immigrants, "may be summarily deported following their apprehension in the colony." 25 It was rare for these Chinese illegal immigrants to successfully obtain asylum in Hong Kong or Macao because of the vast amount of Vietnamese refugees trying to enter these cities. ${ }^{26}$ Fortunately for Mr. Nguyen's sister, she and the passengers on her boat were taken in and sent to a refugee camp by the Hong Kong government.

Back in the state farm in China, Mr. Nguyen, his younger brother, and a small group of people decided to leave for the Portuguese colony of Macao for the same reason why their sister left: to have a better chance in seeking asylum in a western country. In order for them to get to Macao, they secretly paid a bus driver to take them to a city near the Portuguese port colony. They left on the night of 28 May 1980 and reached the city ten days later, leaving their grandparents and sisters at the state farm. From there, they paid another man who was the captain of the boat that was going to take them to Macao. Mr. Nguyen claimed that he had to give the captain everything in his possession. This consisted of 280RMB and a gold ring and a pair of gold earrings that Mr. Nguyen's father had given to him as a future wedding gift before his death. ${ }^{27}$

While it was a much shorter trip compared to others who have fled on a boat, conditions were still dire. The boat that Mr. Nguyen and his brother were on was only suited for 90 people, but approximately 130 people were crammed into it. There was very little food and water. These conditions were very similar to other boats that were boarded by the Vietnamese asylum-seekers. The boat people faced starvation, dehydration, poor living conditions, and the possibility of drowning and even pirate attacks. In a 11 January 1982, New York Times article titled, "Thai Pirates Continuing Brutal Attacks on Vietnamese Boat People", it reported of an incident where one of the boats that held 75 refugee passengers, half of whom were women and children, was attacked by Thai pirates. According to the article, people were robed, tortured, raped and murdered on these tiny boats at the hands of Thai pirates. The United Nations High Commission on Refugees reported that there were " 14 documented incidents of mass murder of Vietnamese boat

\footnotetext{
${ }^{24}$ Morton Beiser, Strangers at the Gate the "Boat People's" First Ten Years in Canada, (Toronto: University of Toronto Press, 1999): 26.

25 PoKempner, 18.

26 Ibid, 18.

${ }^{27}$ Mr. Nguyen, Mr. Nguyen's sister, Interview.
} 
people" in $1981 .^{28}$ There were also 484 confirmed deaths or murders and 583 identified rape victims, as well as abductions of young women and girls. The article stated that the problem stemmed from a lack of patrol of the Thai coastline due to the lack of finance after the American government stopped financing the Thai coastal patrols. ${ }^{29}$ In fact, in a government report by the U.S. Committee of Foreign Affairs titled, "Piracy in the Gulf of Thailand: A Crisis for the International Community," it stated that in 1981, the United States and Thai agreed on a program where the Thai government would receive " $\$ 2.2$ million over 6 months for ships, planes, and other equipment" to prevent pirate attacks. ${ }^{30}$ However, the effort was not effective because the United States government and the Thai government could not agree on a reasonable amount. Furthermore, even if they continued to finance the coastal patrols, they believed it would have exasperated the problem because more refugees would feel compelled to escape by boat knowing that there would be costal patrols protecting the waters, thus increasing the number of refugee boats out in the waters. ${ }^{31}$

While Mr. Nguyen's boat did not encounter any Thai pirates, a couple miles off the shores of Macao, the boat started to leak. Fortunately, one of the passengers, who was an interpreter, was able to catch the attention of coast guards by writing a message on a white sheet and then tied it to a pole. The Macao coast guard pulled their boat to shore, and they were loosely interrogated. They passed the interrogation and were immediately sent to the refugee camp in Macao. Mr. Nguyen said that had it not been for this man and his quick thinking, they may have been sent back to Dongxing. ${ }^{32}$

The refugee camps in Macao were much larger than the ones in Dongxing. According to several repots the refugee camp sites in Macao and Hong Kong were adequate. They provided shelter, food, clean water, and sanitation facilities, along with routine medical care/screening. However, it was reported that diseases and infections were major problems in these overcrowded sites. For example, in W.R.J. Taylor's report, from September 1991 to January 1992, there was a measles epidemic that struck the High Island Hong Kong refugee camp, which opened in November of 1989 and had 7,017 refugees living at the camp at the time of the breakout. At the camp, the Hong Kong Public Health Service (HKPHS) conducted "weekly vaccination sessions" and documented every vaccination. Despite these measures, 272 Vietnamese children were affected, 155 of whom were boys while the other 107 were girls. About ninety percent of these children were between the ages of 5-39 months old. There were two deaths in total. ${ }^{33}$

\footnotetext{
${ }^{28}$ Barbara Crossette, "Thai Pirates Continuing Brutal Attacks on Vietnamese Boat People," New York Times, January 11, 1982, http://www.nytimes.com/1982/01/11/world/thai-pirates-continuing-brutal-attacks-onvietnamese-boat-people.html, (accessed November 28, 2014).

${ }^{29}$ Ibid.

${ }^{30}$ United States. Congress. House. Committee on Foreign Affairs. Subcommittee on Asian and Pacific Affairs, Piracy in the Gulf of Thailand: a crisis for the international community: hearing before the Subcommittee on Asian and Pacific Affairs of the Committee on Foreign Affairs, House of Representatives, Ninety-seventh Congress, second session, April 29, 1982, by Washington, D.C.: U.S. G.P.O., 1982. http://catalog.hathitrust.org/Record/ 011338414 (accessed October 21, 2014): 1.

${ }^{31}$ Ibid, 5.

${ }^{32}$ Mr. Nguyen and Mr. Nguyen's sister, interview.

${ }^{33}$ W. R. J. Taylor, "Measles in Vietnamese Refugee Children in Hong Kong," Epidemiology and Infection, 122, no. 3 (1999): 442-444.
} 
Another case published in 1990 reported that sexually transmitted diseases, more specifically the syphilis virus, was found in 3.4\% (or six) of the pregnant women in the Hong Kong refugee sites. One of the main concerns was that there was a lack of health education provided due to the shortage of skilled interpreters, and that adequate screenings and treatments were needed. ${ }^{34}$

Mental health problems were also an issue. In an article by Kwok B. Chan and David Loveridge, they examined the relationship between culture shock, the conditions of the refugee camps, as well as the emotional and psychological state of the refugees and their journey to seeking permanent residence in the western countries. Post-traumatic stress disorder (PTSD), anxiety, culture shock, depression, and even boredom were some of the mental illnesses that were associated with the premigration, migration, encampment, and postmigration periods of the Vietnamese refugees' journey. In fact, Chan and Loveridge argued that "waiting around" was the major camp activity, and as a result, boredom and uncertainty contributed to the psychological effects it had on the refugees. ${ }^{35}$ Many refugees experienced shifts in emotions: from hope to frustration, which underlined the mental condition that they called the "limbo state" where one "feels forgotten and undesired by the world, almost to the point of losing control of one's own condition," all of which were worsened by the way the camps were organized and the long waiting periods. ${ }^{36}$ However, some of the refugees were able to get past the boredom, anxiety, and hopelessness by finding work. In Hong Kong, there were two types of camps: "open" centers and "closed" centers. Refugees in the "open" camps were allowed to go in and out of the camp site and find outside work. ${ }^{37}$ Mr. Nguyen's sister and her husband was placed in one of these sites. The "closed" camps were the opposite of the "open" camps where the refugees were not allowed to seek outside employment and their movement within and outside of the site was very limited and heavily monitored. ${ }^{38}$ In Macao, Mr. Nguyen was able to find a small job in assembling plastic flowers.

Another way to get past the hopelessness was through religion. Refugees who focused on religion did it for several reasons: the first was because religion and other religious practices were an important part of life in the camps, and that some refugees "had nothing else to do" but to join in on some sort of religious practices. ${ }^{39}$ The second reason was that religion gave people hope and a sense of identity. Many Vietnamese refugees have claimed that during the migration period "religion was a source of hope and comfort," and in turn, "becoming refugees reinforced their faith," and for some it even started their

\footnotetext{
${ }^{34}$ P A King, S J Duthie, and H K Ma, "Sexually Transmitted Diseases amongst Pregnant Vietnamese Refugees in Hong Kong," Genitourin Med, 66, no. 4 (1990): 258, http://www.ncbi.nlm.nih.gov/pmc/articles/ PMC1194525/?tool=pmcentrez\&report=abstract (accessed October 3, 2014).

${ }^{35}$ Kwok B. Chan, and David Loveridge, "Refugees 'in Transit': Vietnamese in a Refugee Camp in Hong Kong," International Migration Review, 21, no. 3 (1987): 746.

${ }^{36}$ Ibid, 746.

37 Ibid, 748.

${ }^{38}$ Chan and Loveridge, 748.

${ }^{39}$ L. J. Dorais, "Faith, Hope and Identity: Religion and the Vietnamese Refugees," Refugee Survey Quarterly, 26, no. 2 (2007): 61, http://library.mtroyal.ca:6494/content/26/2/57 (accessed September 27, 2014).
} 
religious experience as well. ${ }^{40}$ Furthermore, being a part of a religious group helped the refugees integrate much easier to yet another new society when they finally gained permanent residency in countries like Canada.

\section{Final Stages: Resettlement in Canada, Government Programs and Public Opinions}

Most of the refugees that migrated to Canada did so with the help of government sponsorship programs or private sponsorship programs which were often organized by religious group, private corporations, or families and individuals who just wanted to help. When Pierre Trudeau's Liberal government passed the Immigration Act in Canada on 10 April 1978, new provisions were outlined for the fundamental objectives of Canadian immigration policies. For the first time in Canada, refugees were added as a distinct class of immigrants and private sponsorships was encouraged. As a result, huge waves of Vietnamese, Cambodian and Laotian "boat people" arrived in Canada during the Vietnamese refugee crisis.

Canadian public opinion on accepting these Asian refugees were mixed. About a decade earlier, anyone who was not a white Anglo-Saxon protestant, especially those who were from Eastern Europe or were communists, usually had a difficult time immigrating to Canada and faced discrimination. However, it was believed that it was possible to "Canadianize" them. This would become the pre-cursor to the multicultural identity that Canada is today. ${ }^{41}$ Those opposed to accepting the refugees often argued that the refugees would "steal jobs from native-born citizens or choose to not work at all, who use up medical care, social services, or other scarce resources." 42 Those who supported the immigration argued that it was not the case. In a 1979 Globe and Mail opinion piece titled, "Boat people: bonus or burden?" many who wrote to the newspaper claimed that Canada actually needed the resources of immigrants and that many of the "boat people" were highly trained and would contribute to the economy. Others argued that the idea that "charity begins at home" should not just end there. Another writer blamed the refugee crisis directly on "America's criminal intervention in Vietnam" with the help of the Canadian government, therefore, they should take responsibility for their actions.

The difficult task of getting more Canadians involved and aware of the refugee crisis was ambitious, but thanks to three key people, many Canadians were able to help. Howard Adelman, a York University professor developed Operation Lifeline, and with the help of Mike Molloy, the Director of Refugee Affairs, and Ron Atkey, the immigration minister in Joe Clark's Progressive Conservative government in 1979, the program brought in 60,000 boat people to Canada from 1979 to $1980 .^{43}$ Operation Lifeline gained popularity when a graduate student wrote a piece in the Globe and Mail about Adelman's mission in helping the Vietnamese boat people. The article, despite having a mythological tone to it, garnered a lot of attention and included Adelman's phone number. As a result, people from all over

\footnotetext{
${ }^{40}$ Dorais, "Faith, Hope and Identity: Religion and the Vietnamese Refugees," 60.

${ }^{41}$ Franca Iacovetta, Gatekeepers: Reshaping Immigrant Lives in Cold War Canada: Tactic of Close Liaison, (Toronto: Between the Lines, 2006), 105.

${ }^{42}$ Beiser, $\mathrm{x}$.

${ }^{43}$ Peter Goodspeed, "Can Canada Duplicate Its Boat People Rescue with Syrian Refugees?" The Star, September 26, 2014, Atkinson Series sec. Accessed July 29, 2015. http://www.thestar.com/news/ atkinsonseries/2014/09/26/can_canada_duplicate_its_boat_people_rescue_with_syrian_refugees.html.
} 
Canada were calling in asking how they could help and within 10 days, 68 chapters of Operation Lifeline were created all across Canada. ${ }^{44}$ Many volunteers helped the program succeed by simply taking phone calls, taking in donations and keeping records for the new chapters. Initially, 9,000 refugees came to Canada between 1975 and 1978, but as more Canadians became involved, more than 34,000 Vietnamese refugees came to Canada, more than 21,000 of whom were sponsored by private organizations. ${ }^{45}$ By the end of July in 1979, the Canadian government agreed to match up to 50,000 of the privately sponsored refugees to Canada. The government-match-sponsorship program initially brought in 40,000 refugees in total, but with the mounting public pressure the Canadian government ended up sponsoring a total of 60,000 refugees from 1979 to $1981 .{ }^{46}$

Back in the refugee camps, the criteria of deciding which refugee was allowed to migrate to Canada was also a somewhat looser process. In a 1979 CBC interview, Canadian Immigration Officer Scott Mullin loosely explained how his job was performed and his opinions related to the Indochinese refugee crisis. He said that more often than not, if a refugee spoke English or French, had a relative in Canada, or worked in the trades industry and other desirable professions, especially before 1975 - the time before the communist regime took over in Vietnam, they were generally accepted. Most of his decisions, Mullin said, were based on a "gut feeling" as to whether or not these refugees were telling the truth, and his belief of whether they would successfully integrate to Canadian society. However, Mullin rejected more refugees than he accepted..$^{47}$

Most refugees who were fortunate enough to immigrate to Canada could rely on programs provided by the government, host programs and volunteers to help them ease into Canadian society. Schools, health care, transportation and recreation were provide by the government, while private sponsors were "obliged to provide financial support for the person or family they sponsored for a period of one year, or until the person or family had achieved financial stability." 48 Despite these programs, integrating into a new society was still very difficult due to the cultural differences, and the fact that not all of the programs that were provided were helpful. Issues like culture shock, language barriers, and posttraumatic stress disorders were still present. Nonetheless, most refugees tried to do their best.

Mr. Nguyen and his younger brother were both sponsored by a private Christian sponsorship organization from Winnipeg, Manitoba. Because their younger sister and her family were already in Canada a couple of months earlier, she was able to sponsor her two brothers through the same organization. On 14 November 1980, they both arrived in Montreal. From there, they were brought to Winnipeg and then to Calgary where they were reunited with their sister. With all new immigrants, they were expected to repay the

\footnotetext{
${ }^{44}$ Goodspeed, "Can Canada Duplicate Its Boat People Rescue with Syrian Refugees?".

${ }^{45}$ Robert Bothwell, "Canada-United States Relations: Options for the 1970s," International Journal, 58, no. 1 (2002): 77, http://www.jstor.org/stable/40203813 (accessed November 1, 2014).

${ }^{46}$ Beiser, 42-43.

${ }^{47}$ Scott Mullin, (Immigration Officer), interview by Peter Mansbridge, Hong Kong" The one-man board of immigration," CBC Digital Archives, Podcast Video, July 9, 1979, December 1, 2014, http://www.cbc.ca/ archives/categories/society/immigration/boat-people-a-refugee-crisis/the-one-man-board-ofimmigration.html.

${ }^{48}$ Beiser, 120-121.
} 
government for the plane fee which was about $\$ 600$ each. Within three days of arriving in Calgary, Mr. Nguyen found a job as a kitchen cabinet maker while his brother, who was 16 years old at that time attended public school. For the next 34 years, they continued to work, live and create a new life in Calgary. Within those years they also managed to sponsor two other sisters as well.

\section{Conclusion}

The stories and the experiences of the Vietnamese refugees or the "boat people" is one that is unique and distressing. The crisis changed the way the world would respond to refugee crises, especially in Canada during the counter-culture era. It changed the Canadian identity and help foster the idea of multiculturalism in Canada. More than one million Vietnamese people either left or were forced out of their country. Those who fled by boat suffered difficult hardships like starvation, dehydration, drowning, and even pirate attacks. The refugee camps were just as difficult due to crowding and hard living conditions. Between 1975 and 1984, the United States accepted 58.9\% $(67,412)$ of the refugees from Hong Kong, while Canada accepted $15.4 \%(15,588)$ of them. ${ }^{49}$ In total, Canada accepted more than 100,000 Vietnamese people during the late 1970s to the 1980s. Those who were fortunate to have been sponsored by western nations, like the Nguyen family, were able to create a new life in a new country.

\footnotetext{
${ }^{49}$ Chan and Loveridge, 748.
} 
PRIMARY SOURCES:

Bibliography

Butterfiled, Fox. "Hanoi Regime Reported Resolve to Oust Nearly All Ethnic Chinese." The New York Times, June 12, 1979. http://www.paulbogdanor.com/left/vietnam/ boatpeople1.pdf (accessed November 28, 2014).

Central Intelligence Agency, and the Defense Intelligence Agency. "An Appraisal of the Bombing of North Vietnam (1 April - 30 June 1968)." Central Intelligence Agency Collection. Folder 148, Box 11, (MORI Document ID: 14451:14451). The Vietnam Center and Archive, Texas Tech University, July 1968. Accessed November 29, 2014. <http://www.vietnam.ttu.edu/virtualarchive/items.php?item=04111148001>.

Crossette, Barbara. "Thai Pirates Continuing Brutal Attacks on Vietnamese Boat People." New York Times, January 11, 1982. http://www.nytimes.com/1982/01/11/ world/thai-pirates-continuing-brutal-attacks-on-vietnamese-boat-people.html (accessed November 28, 2014).

Director of Intelligence. "Intelligence Memorandum: An Appraisal of the Bombing of North Vietnam (Through 14 June)." Central Intelligence Agency Collection. Folder 27, Box 02, (MORI Document ID: 9128:9128). The Vietnam Center and Archive, Texas Tech University, June 20, 1966. Accessed November 29, 2014. http:// www.vietnam.ttu.edu/virtualarchive/items.php?item=0410227010.

King, P A, S J Duthie, and H K Ma. "Sexually Transmitted Diseases amongst Pregnant Vietnamese Refugees in Hong Kong." Genitourin Med. 66, no. 4 (1990): 257-58. Accessed October 3, 2014. http://www.ncbi.nlm.nih.gov/pmc/articles/ PMC1194525/?tool=pmcentrez\&report=abstract

Mullin, Scott. "The one-man board of immigration." CBC Digital Archives, July 9, 1979. December 1, 2014. http://www.cbc.ca/archives/categories/society/immigration/ boat-people-a-refugee-crisis/the-one-man-board-of-immigration.html.

Puri, Belle. "Why they Fled: The fall of Saigon." CBC Digital Archives. CBC May 1 2000. Web, http://www.cbc.ca/archives/categories/society/immigration/boat-people-arefugee-crisis/why-they-fled-the-fall-of-saigon.html.

Taylor, W. R. J. "Measles in Vietnamese Refugee Children in Hong Kong." Epidemiology and Infection. 122, no. 3 (1999): 441-46. Accessed September 26, 2014. http:// www.ncbi.nlm.nih.gov/pmc/articles/PMC2809639/? tool=pmcentrez\&report=abstract

United States. Congress. House. Committee on Foreign Affairs. Subcommittee on Asian and Pacific Affairs. Piracy in the Gulf of Thailand: a crisis for the international community: hearing before the Subcommittee on Asian and Pacific Affairs of the Committee on Foreign Affairs, House of Representatives, Ninety-seventh Congress, second session, April 29, 1982. By Washington, D.C.: U.S. G.P.O., 1982. http://catalog.hathitrust.org/Record/ 011338414 (accessed October 21, 2014). 


\section{SECONDARY SOURCES}

Beiser, Morton. Strangers at the Gate the "Boat People's" First Ten Years in Canada. Toronto, Ont.: University of Toronto Press, 1999.

Bothwell, Robert. "Canada-United States Relations: Options for the 1970s." International Journal. no. 1 (2002): 65-88. http://www.jstor.org/stable/40203813 (accessed November 1, 2014).

Chan, Kwok B., and David Loveridge. "Refugees 'in Transit': Vietnamese in a Refugee Camp in Hong Kong." International Migration Review. 21, no. 3 (1987): 745-59. Accessed September 27, 2014. http://library.mtroyal.ca:2102/stable/2546620.

Chan, Sucheng. The Vietnamese American 1.5 Generation: Stories of War, Revolution, Flight, and New Beginnings. Philadelphia, PA: Temple University Press, 2006.

Dorais, L. J. "Faith, Hope and Identity: Religion and the Vietnamese Refugees." Refugee Survey Quarterly. 26, no. 2 (2007): 57-68. Accessed September 27, 2014. http:// library.mtroyal.ca:6494/content/26/2/57.

Iacovetta, Franca. Gatekeepers: Reshaping Immigrant Lives in Cold War Canada: Tactic of Close Liaison. Toronto: Between the Lines, 2006.

Mark, Bradley Philip. Vietnam at war. Oxford: Oxford University Press, 2009.

PoKempner, Dinah. "Indefinite Detention and Mandatory Repatriation: The Incarceration of Vietnamese in Hong Kong." Pacific Basin Law Journal. no. 2 (1992): 1-38. http:// escholarship.org/uc/item/5k50w30x?query=dongxing;hitNum=1

Wilson, Stephen W. "Taking Clodfelter One Step Further: Mass, Surprise, Concentration, And The Failure of Operation Rolling Thunder." Air Power History. no. 4 (2001): 40-47. http://library.mtroyal.ca:2081/docview/219749982?pq-origsite=summon (accessed November 8, 2014). 